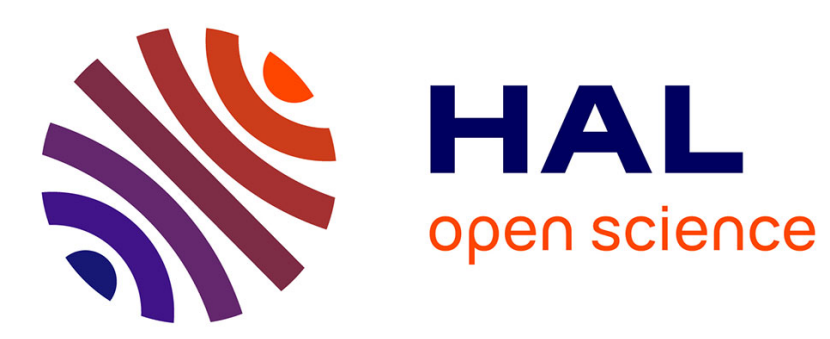

\title{
Tax Me If You Can! Optimal Nonlinear Income Tax Between Competing Governments
}

\author{
Etienne Lehmann, Laurent Simula, Alain Trannoy
}

\section{To cite this version:}

Etienne Lehmann, Laurent Simula, Alain Trannoy. Tax Me If You Can! Optimal Nonlinear Income Tax Between Competing Governments. 2013. halshs-00870053

\section{HAL Id: halshs-00870053 \\ https://shs.hal.science/halshs-00870053}

Preprint submitted on 4 Oct 2013

HAL is a multi-disciplinary open access archive for the deposit and dissemination of scientific research documents, whether they are published or not. The documents may come from teaching and research institutions in France or abroad, or from public or private research centers.
L'archive ouverte pluridisciplinaire HAL, est destinée au dépôt et à la diffusion de documents scientifiques de niveau recherche, publiés ou non, émanant des établissements d'enseignement et de recherche français ou étrangers, des laboratoires publics ou privés. 


\section{Tax Me If You Can!}

\section{Optimal Nonlinear Income Tax Between Competing Governments}

ETIENNE LeHMANN, LAURENT SimUla, ALAin TRANNOY

TEPP - Travail, Emploi et Politiques Publiques - FR CNRS 3126 


\title{
Tax Me If You Can! \\ Optimal Nonlinear Income Tax between Competing Governments*
}

\author{
Etienne LEHMANN ${ }^{+}$ \\ CREST and CRED (TEPP) Université Panthéon-Assas \\ Laurent SIMULA $\ddagger$ \\ Uppsala Center for Fiscal Studies \& Department of Economics, Uppsala University \\ Alain TRANNOY \\ Aix-Marseille Université (Aix-Marseille School of Economics) CNRS EHESS
}

September 24, 2013

\begin{abstract}
We investigate how potential tax-driven migrations modify the Mirrlees income tax schedule when two countries play Nash. The social objective is the maximin and preferences are quasilinear in income. Individuals differ both in skills and migration costs, which are continuously distributed. We derive the optimal marginal income tax rates at the equilibrium, extending the Diamond-Saez formula. The theory and numerical simulations on the US case show that the level and the slope of the semi-elasticity of migration on which we lack empirical evidence are crucial to derive the shape of optimal marginal income tax. Our simulations show that potential migrations result in a welfare drop between $0.4 \%$ and $5.3 \%$ for the worst-off and an average gain between $18.9 \%$ and $29.3 \%$ for the top $1 \%$.
\end{abstract}

JEL Classification: D82, H21, H87

Keywords: Optimal Income Tax, Income Tax competition, Migration, Labor Mobility, NashEquilibrium Tax Schedules

\footnotetext{
${ }^{*}$ We are grateful to participants to seminars at CREST, Ecole Polytechnique, UCFS workshop, the University of Mannheim, the University of Rennes (CREM), the University of Panthéon Assas Paris 2, the ENS-Cachan/Paris-Sud Hotelling seminar, the University of Cergy (THEMA), the IIES (Stockholm), the University of Bayreuth and ESEM 2013. We in particular would like to thank Spencer Bastani, Craig Brett, Sören Blomquist, Tomer Blumkin, Pierre Boyer, Nathalie Ethchart-Vincent, John Hassler, Laurence Jacquet, Eckhart Janeba, Hubert Kempf, Jean-Baptiste Michau,Fabien Moizeau, Olle Folke, Sebastian Koehne, Per Krusell, Ali Sina Onder, Torsten Persson, Régis Renault, Emmanuel Saez, Håkan Selin, Emmanuelle Taugourdeau, Farid Toubal, Bruno Van der Linden and John D. Wilson.

${ }^{\dagger}$ Address: CRED, Université Panthéon-Assas Paris 2, 12 place du Panthéon, 75231 Paris Cedex 05, France. Email: etienne.lehmann@ensae.fr. Etienne Lehmann is also research fellow at IRES-Université Catholique de Louvain, IDEP, IZA and CESifo and junior research fellow of Institut Universitaire de France.

‡Address: Uppsala Center for Fiscal Studies (UCFS) and Department of Economics, Uppsala University, Box 513, SE-751 20 Uppsala, Sweden. Email: laurent.simula@nek.uu.se Laurent Simula is also research fellow at CESifo and a research associate at Centre d'Economie de la Sorbonne - Ecole Normale Supérieure de Cachan.

$\S$ Address: Aix-Marseille Université (Aix-Marseille School of Economics), CNRS and EHESS. 2, rue de la Charité, 13002 Marseille, France. Email: alain.trannoy@univmed.fr
} 